This Accepted Author Manuscript is copyrighted and published by Elsevier. It is posted here by agreement between Elsevier and University of Brasilia. Changes resulting from the publishing process - such as editing, corrections, structural formatting, and other quality control mechanisms - may not be reflected in this version of the text. The definitive version of the text was subsequently published in [Animal Reproduction Science, Volume 56, Issues 3-4, 16 August 1999, Pages 223-236, doi:10.1016/S0378-4320(99)00045-7].You may download, copy and otherwise use the AAM for non-commercial purposes provided that your license is limited by the following restrictions:

(1) You may use this AAM for non-commercial purposes only under the terms of the CC-BY-NCND license.

(2) The integrity of the work and identification of the author, copyright owner, and publisher must be preserved in any copy.

(3) You must attribute this AAM in the following format: [agreed attribution language, including link to CC BY-NC-ND license + Digital Object Identifier link to the published journal article on Elsevier's ScienceDirect ${ }^{\circledR}$ platform].

Este Manuscrito do Autor Aceito para Publicação (AAM) é protegido por direitos autorais e publicado pela Elsevier. Ele esta disponível neste Repositório, por acordo entre a Elsevier e a Universidade de Brasília. As alterações decorrentes do processo de publicação - como a edição, correção, formatação estrutural, e outros mecanismos de controle de qualidade - não estão refletidas nesta versão do texto. A versão definitiva do texto foi posteriormente publicado em [Animal Reproduction Science, Volume 56, Número 3-4, 16 de Agosto de 1999, Páginas 223-236, doi:10.1016/S0378-4320(99)00045-7]. Você pode baixar, copiar e utilizar de outra forma o AAM para fins não comerciais, desde que sua licença seja limitada pelas seguintes restrições:

(1) Você pode usar este AAM para fins não comerciais apenas sob os termos da licença CC- BYNC-ND.

(2) A integridade do trabalho e identificação do autor, detentor dos direitos autorais e editor deve ser preservado em qualquer cópia.

(3) Tem de atribuir este AAM no seguinte formato: [acordo na linguagem atribuída, incluindo o link para CC BY-NC-ND licença Digital + DOI do artigo publicado na revista Elsevier ScienceDirect ${ }^{\circledR}$ da plataforma]. 


\title{
Study of preantral follicle population in situ and after mechanical isolation from caprine ovaries at different reproductive stages
}

\author{
C.M. Lucci \\ C.A. Amorima \\ A.P.R. Rodrigues \\ J.R. Figueiredo \\ S.N. Báo \\ J.R.V. Silva \\ P.B.D. Gonçalves
}

\begin{abstract}
The purposes of this study were to estimate the population of caprine preantral follicles, and to evaluate quantitatively and qualitatively the efficiency of a specific mechanical method for the isolation of preantral follicles from mixed breed goats at different reproductive stages. On average, $37,646 \pm 4277$ preantral follicles were present in goat ovaries, and $13,631 \pm 2399$ preantral follicles were obtained after isolation. The number of preantral follicles isolated or in situ was not significantly affected by the reproductive stage. The mean recovery rate per ovary ([number of isolated follicles/number of in situ follicles] $\times 100$ ) of isolated follicles was $36.2 \%$. The distribution of follicles in situ was $67.8 \%$ primordial, $25.8 \%$ primary and $6.4 \%$ secondary; the respective distribution after isolation was $93.8 \%, 5.2 \%$ and $1.0 \%$. In this study, many polyovular follicles were also observed, mainly in prepubertal goat ovaries. Histological analysis showed that few preantral follicles were atretic in situ $(4.83 \% \pm 0.35)$ or after the isolation procedure $(4.67 \% \pm 0.65)$ in the three reproductive stages. The percentage of atretic follicles was not affected either by the mechanical method or by the reproductive stage. It is concluded that a large number of preantral follicles can be successfully isolated mechanically, with a high recovery rate and a low rate of follicular atresia, irrespective of the reproductive stage of the caprine female.
\end{abstract}

Keywords: Preantral follicle; Follicle isolation; Histology; Polyovular follicle; Goat

\section{Introduction}

At birth, the mammalian ovary contains a large store of follicles of which only a small number will be used during the reproductive lifespan of the female. The total follicular population in the mammalian ovary consists of a large reserve of quiescent primordial follicles and a much smaller number of follicles in the growth phase (Cahill and Mauléon, 1981). There are on average 130,000 and 80,000 primordial follicles, respectively, in bovine (Erickson, 1966b) and ovine (Land, 1970) ovaries. Moreover, the preantral follicular population may be affected by many factors including age (Erickson, 1966a and Erickson, 1966b), breed (Cahill et al., 1979), hormone concentration and reproductive state (Erickson et al., 1976). Despite this great population of preantral follicles, the vast majority becomes atretic during their growth and maturation. This represents an enormous loss of genetic material. 
Development of techniques for rescue and in vitro growth of preantral follicles would be an addition to the methods already available for animal reproduction (e.g. artificial insemination, embryo transfer, in vitro fertilization and cloning), since it would supply a large and uniform population of oocytes from genetically superior animals (Betteridge et al., 1989). In the last decades, various techniques for isolating preantral follicles have been reported for pigs (Greenwald and Moor, 1989; Lazzari et al., 1992), cows (Figueiredo et al., 1993; Nuttinck et al., 1993; Hulshof et al., 1994), cats (Jewgenow and Pitra, 1993; Jewgenow and Göritz, 1995) and ewes (Amorim et al., 1998b).

In goats, a specific mechanical method for the isolation of a great number of intact preantral follicles per ovary was recently developed (Lucci et al., 1999). However, the efficiency of this method for the isolation of preantral follicles from caprine ovaries at different reproductive stages is unknown. In general, the efficiency of isolation methods is difficult to determine for lack of comparative studies between the number of preantral follicles present in the ovary and the number of preantral follicles isolated from the same ovary. In addition, for goats no information is available concerning the population of preantral follicles present in the ovaries.

The aims of the present study were: first, to estimate the population of caprine preantral follicles in situ, and secondly, to perform quantitative and qualitative analysis of the efficiency of the mechanical method for the isolation of preantral follicles from goats at different reproductive stages, using as a control the number of preantral follicles present in situ.

\section{Materials and methods}

\subsection{Source of ovaries}

In this study, 18 ovaries from prepubertal ( $2-3$ months of age; $n-6)$, non-pregnant $(n-6)$ and pregnant adult goats ( $1-3$ years old; $n-6)$ were collected at a local slaughterhouse. It is important to note that only one ovary from each animal was taken, and that all the ovaries were from mixed breed goats. The ovaries were washed in $70 \%$ alcohol for approximately $10 \mathrm{~s}$ and then, twice in $0.9 \%$ saline solution. Finally, each ovary was transferred to $10 \mathrm{ml}$ of phosphate buffered saline (PBS) and transported to the laboratory within $1 \mathrm{~h}$ in a thermoflask filled with water at $39^{\circ} \mathrm{C}$. 


\subsection{Experimental protocol}

To evaluate qualitatively and quantitatively the efficiency of the specific mechanical method for the isolation of caprine preantral follicles, described below, each ovary was cut longitudinally into two halves. One half was used to isolate preantral follicles and the other one was used to study the preantral follicle population in situ (Fig. 1).

Preantral follicles were isolated from the ovarian halves by applying the specific mechanical procedure developed for the isolation of caprine preantral follicles described previously by Lucci et al. (1999). Briefly, the ovarian tissue was cut into small fragments using a tissue chopper (The Mickle Laboratory Engineering Co., Gomshal, Surrey, UK) adjusted to 75 $\mu \mathrm{m}$. The ovarian fragments were placed in PBS plus $5 \%$ caprine serum and then pipetted 40 times with a large pasteur pipette (diameter $\sim 1600 \mu \mathrm{m}$ ) and 40 times with a smaller pipette (diameter $\sim 600 \mu \mathrm{m}$ ). The suspension was filtered successively through 500 and $100 \mu \mathrm{m}$ nylon mesh filters. The number of isolated preantral follicles in the suspension containing fragments $<100 \mu \mathrm{m}$ was counted and classified using an inverted microscope (Zeiss). The follicular diameters were measured with an ocular micrometer. Preantral follicles were classified according to the stage of development as primordial (one layer of flattened or flattenedcuboidal granulosa cells around the oocyte), primary (a single layer of cuboidal granulosa cells around the oocyte), or secondary (oocyte surrounded by more than one complete layer of cuboidal granulosa cells) (Hulshof et al., 1994).

To evaluate the quality of the isolated preantral follicles, they were prefixed in $2 \%$ paraformaldehyde, $2.5 \%$ glutaraldehyde and $0.1 \mathrm{M}$ sodium cacodylate buffer, for $30 \mathrm{~min}$ at room temperature. The follicles of each class were embedded in drops of $200 \mu \mathrm{l}$ of $4 \%$ agar solution (agarose, type VII, Sigma, St. Louis, MO, USA). The agar drops were fixed in the same fixation solution described above for $3 \mathrm{~h}$. The drops were dehydrated, embedded in paraffin wax, sectioned serially at a thickness of $7 \mu \mathrm{m}$ and stained with periodic acid schiff (PAS) and haematoxylin. Follicular quality was evaluated based on the integrity of the basement membrane, cellular density, presence or absence of pycnotic bodies and integrity of the oocyte. Based on these parameters, preantral follicles were classified as morphologically normal or degenerated follicles. 


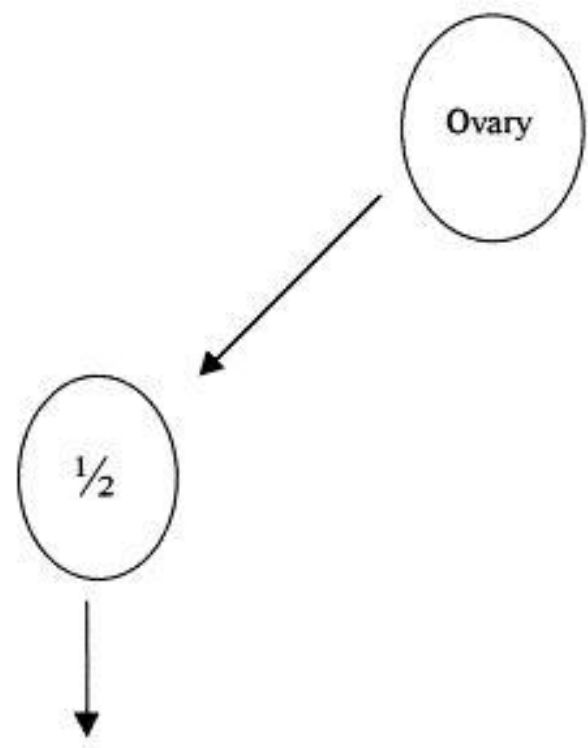

Tissue chopper - $75 \mu \mathrm{m}$

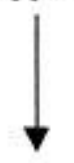

Mechanical dissociation (pasteur pipettes - 1600 and $600 \mu \mathrm{m}$ )

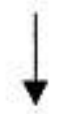

Filtration (500 and $100 \mu \mathrm{m})$

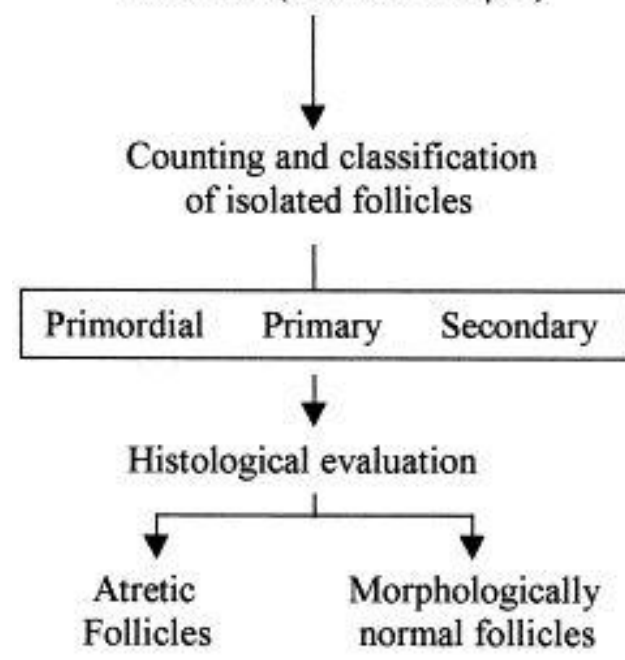

Estimation and classification of in situ preantral follicular population

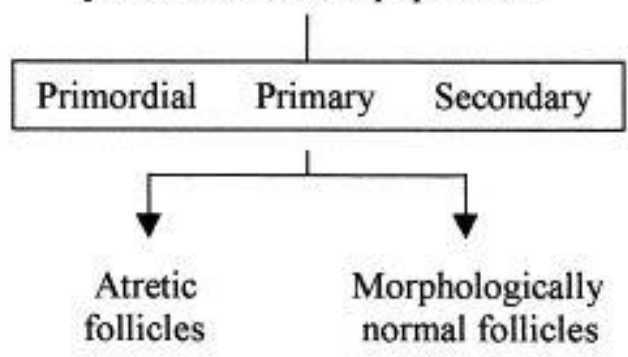

Fig. 1. Experimental protocol to study caprine preantral follicle population in situ and after isolation procedure.

In order to estimate the preantral follicular population in caprine ovaries, the ovarian halves that were not used to isolate preantral follicles were fixed in $10 \%$ formaldehyde and processed for histology. Tissue was serially sectioned at $7 \mu \mathrm{m}$ and stained with PAS and haematoxylin. The number of preantral follicles was estimated by counting the follicles in every 120th section (Cahill et al., 1979) using the nucleus of the oocyte as a marker and the 
correction factor described by Gougeon and Chainy (1987). Preantral follicles were classified based on their morphology (primordial, primary and secondary) and quality (morphologically normal and degenerated follicles) as described above. The diameter of the follicles and the oocytes was determined when the nucleolus of the oocyte was observed.

For each ovary, the recovery rate (RR) of follicles isolated by the mechanical method was calculated as follows: RR per ovary=(number of isolated follicles/number of in situ follicles) $\times 100$.

\subsection{Statistical analysis of data}

Analysis of variance and Fisher's PLSD test (Stat View for Macintosh) were used to compare: (1) the mean number of preantral follicles isolated and in situ among the different reproductive stages (prepubertal, non-pregnant and pregnant adult animals), (2) the mean number of preantral follicles that were isolated and observed in situ in each reproductive stage, and (3) the mean follicular recovery rate among reproductive stages. Data were log transformed if Hartley's test indicated heterogeneity of variance. The diameter of preantral follicles, in situ and isolated, were compared by Scheffe's test (Stat View for Macintosh). Comparisons between the percentages of atretic preantral follicles isolated and in situ in each reproductive stage and among reproductive stages were analyzed by Chi-square (Instat for Macintosh). Values were considered statistically significant when $p<0.05$.

\section{Results}

\subsection{Number of preantral follicles isolated and in situ}

Table 1 shows the number of preantral follicles in situ and isolated and the recovery rate of preantral follicles for prepubertal, non-pregnant and pregnant adult goats. Large individual variation was observed in the number of isolated and in situ preantral follicles in all the three reproductive stages. In all reproductive stages the number of isolated follicles was significantly lower that those observed in situ. No significant differences were observed among reproductive stages, neither for the number of isolated and in situ preantral follicles nor for the recovery rate. The mean recovery rate per ovary ([number of isolated follicles/number of in situ follicles]×100) varied from $28.3 \%$ (prepubertal) to $45.7 \%$ (pregnant goats). 
Table 1

Number of in situ and isolated preantral follicles per ovary and follicular recovery rate in prepubertal, non-pregnant, and pregnant adult goats (mean \pm s.e.m.)

\begin{tabular}{llll}
\hline Reproductive stage & \multicolumn{2}{l}{ Number of preantral follicles per ovary (range) } & Isolated \\
\cline { 2 - 4 } & $N$ (ovaries) & In situ & $11,933 \pm 3029^{\mathrm{b}}(3024-22,064)$ \\
Prepubertal & 6 & $45,127 \pm 7784^{\mathrm{a}}(23,623-66,477)$ & $28.3 \pm 7.5$ \\
Non-pregnant adults & 6 & $32,204 \pm 4583^{\mathrm{a}}(20,497-44,659)$ & $12,017 \pm 3379^{\mathrm{b}}(1764-22,288)$ \\
Pregnant adults & 6 & $35,608 \pm 9329^{\mathrm{a}}(20,122-80,739)$ & $16,945 \pm 5899^{\mathrm{b}}(1456-35,000)$ \\
Total & 18 & $37,646 \pm 4277^{\mathrm{a}}(20,122-80,739)$ & $13,631 \pm 2399^{\mathrm{b}}(1456-35,000)$ \\
\hline
\end{tabular}

${ }^{\mathrm{a}, \mathrm{b}}$ Values with different superscripts in the same row are significantly different $(p<0.0001)$. 
Table 2

Mean number and percentage of primordial, primary and secondary follicles in situ and isolated per ovary of prepubertal, non-pregnant and pregnant goats $($ mean \pm s.e.m.)

\begin{tabular}{|c|c|c|c|c|c|c|c|c|c|}
\hline \multirow[t]{3}{*}{ Follicle class } & \multicolumn{8}{|c|}{ Number and percentage of preantral follicles per ovary (mean \pm s.e.m.) } & \multirow{3}{*}{$\begin{array}{l}\text { Recovery } \\
\text { rate }(\%)\end{array}$} \\
\hline & \multicolumn{2}{|c|}{ Prepubertal } & \multicolumn{2}{|c|}{ Non-pregnant adults } & \multicolumn{2}{|l|}{ Pregnant adults } & \multicolumn{2}{|l|}{ Total } & \\
\hline & In situ & Isolated & In situ & Isolated & In situ & Isolated & In situ & Isolated & \\
\hline Primordial & $\begin{array}{l}32,175 \pm 6279^{\mathrm{aA}} \\
(69.2 \% \pm 3.5)^{\mathrm{aD}}\end{array}$ & $\begin{array}{l}11,297 \pm 2958^{\mathrm{bA}} \\
(94.1 \% \pm 1.8)^{\mathrm{bD}}\end{array}$ & $\begin{array}{l}20,779 \pm 4116^{\mathrm{aA}} \\
(61.9 \% \pm 6.4)^{\mathrm{aD}}\end{array}$ & $\begin{array}{l}11,326 \pm 3384^{\mathrm{bA}} \\
(90.7 \% \pm 4.0)^{\mathrm{bD}}\end{array}$ & $\begin{array}{l}26,887 \pm 8369^{\mathrm{aA}} \\
(72.1 \% \pm 6.3)^{\mathrm{aD}}\end{array}$ & $\begin{array}{l}16,427 \pm 5746^{\mathrm{bA}} \\
(96.5 \% \pm 0.4)^{\mathrm{bD}}\end{array}$ & $\begin{array}{l}26,613 \pm 3697^{\mathrm{aA}} \\
(67.8 \% \pm 3.2)^{\mathrm{aD}}\end{array}$ & $\begin{array}{l}13,010 \pm 2358^{\mathrm{bA}} \\
(93.8 \% \pm 1.5)^{\mathrm{bD}}\end{array}$ & $50.2 \pm 7.8^{\mathrm{G}}$ \\
\hline Primary & $\begin{array}{l}10,668 \pm 1317^{\mathrm{aB}} \\
(26.1 \% \pm 3.7)^{\mathrm{aE}}\end{array}$ & $\begin{array}{l}555 \pm 184^{\mathrm{bB}} \\
(5.0 \% \pm 1.7)^{\mathrm{bE}}\end{array}$ & $\begin{array}{l}9702 \pm 1226^{\mathrm{aB}} \\
(31.4 \% \pm 4.4)^{\mathrm{aE}}\end{array}$ & $\begin{array}{l}532 \pm 197^{\mathrm{bB}} \\
(7.8 \% \pm 2.9)^{\mathrm{bE}}\end{array}$ & $\begin{array}{l}6515 \pm 1483^{\mathrm{aB}} \\
(20.0 \% \pm 4.3)^{\mathrm{aE}}\end{array}$ & $\begin{array}{l}453 \pm 156^{\mathrm{bB}} \\
(3.0 \% \pm 0.3)^{\mathrm{bE}}\end{array}$ & $\begin{array}{l}8962 \pm 847^{\mathrm{aB}} \\
(25.8 \% \pm 2.5)^{\mathrm{aE}}\end{array}$ & $\begin{array}{l}513 \pm 98^{\mathrm{bB}} \\
(5.2 \% \pm 1.2)^{\mathrm{bE}}\end{array}$ & $5.9 \pm 0.5^{\mathrm{H}}$ \\
\hline Secondary & $\begin{array}{l}2284 \pm 532^{\mathrm{aC}} \\
(4.7 \% \pm 0.4)^{\mathrm{aF}}\end{array}$ & $\begin{array}{l}98 \pm 21^{\mathrm{bC}} \\
(0.9 \% \pm 0.1)^{\mathrm{bF}}\end{array}$ & $\begin{array}{l}1722 \pm 480^{\mathrm{aC}} \\
(6.7 \% \pm 2.3)^{\mathrm{aF}}\end{array}$ & $\begin{array}{l}159 \pm 52^{\mathrm{bC}} \\
(1.5 \% \pm 0.9)^{\mathrm{bF}}\end{array}$ & $\begin{array}{l}2207 \pm 396^{\mathrm{aC}} \\
(7.9 \% \pm 2.4)^{\mathrm{aF}}\end{array}$ & $\begin{array}{l}65 \pm 29^{\mathrm{bC}} \\
(0.5 \% \pm 0.2)^{\mathrm{bF}}\end{array}$ & $\begin{array}{l}2071 \pm 263^{\mathrm{aC}} \\
(6.4 \% \pm 1.1)^{\mathrm{aF}}\end{array}$ & $\begin{array}{l}107 \pm 22^{\mathrm{bC}} \\
(1.0 \% \pm 0.4)^{\mathrm{bF}}\end{array}$ & $5.5 \pm 1.9^{\mathrm{H}}$ \\
\hline Total & $\begin{array}{l}45,127 \pm 7784 \\
(100 \%)\end{array}$ & $\begin{array}{l}11,933 \pm 3029 \\
(100 \%)\end{array}$ & $\begin{array}{l}32,204 \pm 4583 \\
(100 \%)\end{array}$ & $\begin{array}{l}12,017 \pm 3379 \\
(100 \%)\end{array}$ & $\begin{array}{l}35,608 \pm 9329 \\
(100 \%)\end{array}$ & $\begin{array}{l}16,945 \pm 5899 \\
(100 \%)\end{array}$ & $\begin{array}{l}37,646 \pm 4277 \\
(100 \%)\end{array}$ & $\begin{array}{l}13,631 \pm 2399 \\
(100 \%)\end{array}$ & $36.2 \pm 5.8$ \\
\hline
\end{tabular}

${ }^{\mathrm{a}, \mathrm{b}}$ Values with different superscripts in the same row within reproductive stage are significantly different $(p<0.0003)$.

$\mathrm{A}, \mathrm{B}, \mathrm{C}$ Values with different superscripts in the same column are significantly different $(p<0.0001)$; concerning to number of follicles.

$\mathrm{D}, \mathrm{E}, \mathrm{F}$ Values with different superscripts in the same column are significantly different $(p<0.0001)$; concerning to percentage of follicles.

${ }^{\mathrm{G}, \mathrm{H}}$ Values with different superscripts in the same column are significantly different $(p=0.0005)$; concerning to recovery rate. 
Reproductive stages did not affect the proportions of primordial, primary and secondary follicles observed in situ or after mechanical isolation. However, the proportions of preantral follicle classes obtained after mechanical isolation were significantly different to those observed in situ in all the three reproductive stages. The mean number of primordial, primary and secondary follicles in situ and after isolation and their corresponding proportions in the three reproductive stages are shown in Table 2. Taking the reproductive stages together, for the preantral follicle population in situ and after isolation, the proportions of primordial, primary and secondary follicles were $67.8 \%$ and $93.8 \%, 25.8 \%$ and $5.2 \%, 6.4 \%$ and $1.0 \%$, respectively. The mechanical method isolated mainly primordial follicles. The mean recovery rate per follicular class was $50.2 \%, 5.9 \%$ and $5.5 \%$, respectively for primordial, primary and secondary follicle classes (Table 2).

\subsection{Morphometric analysis of preantral follicles in situ and after isolation}

Histological analysis in situ showed that primordial follicles have an oocyte surrounded by one layer of squamous or squamous-cuboidal granulosa cells; primary follicles have a single layer of cuboidal granulosa cells, and secondary follicles have an oocyte surrounded by two or more layers of cuboidal granulosa cells (Fig. 2). Freshly isolated primordial, primary, and secondary follicles in the suspension were spherical and appeared healthy under the inverted microscope. After isolation, the oocytes of primary and secondary follicles were not always clearly visible because of granulosa cells covering them. 

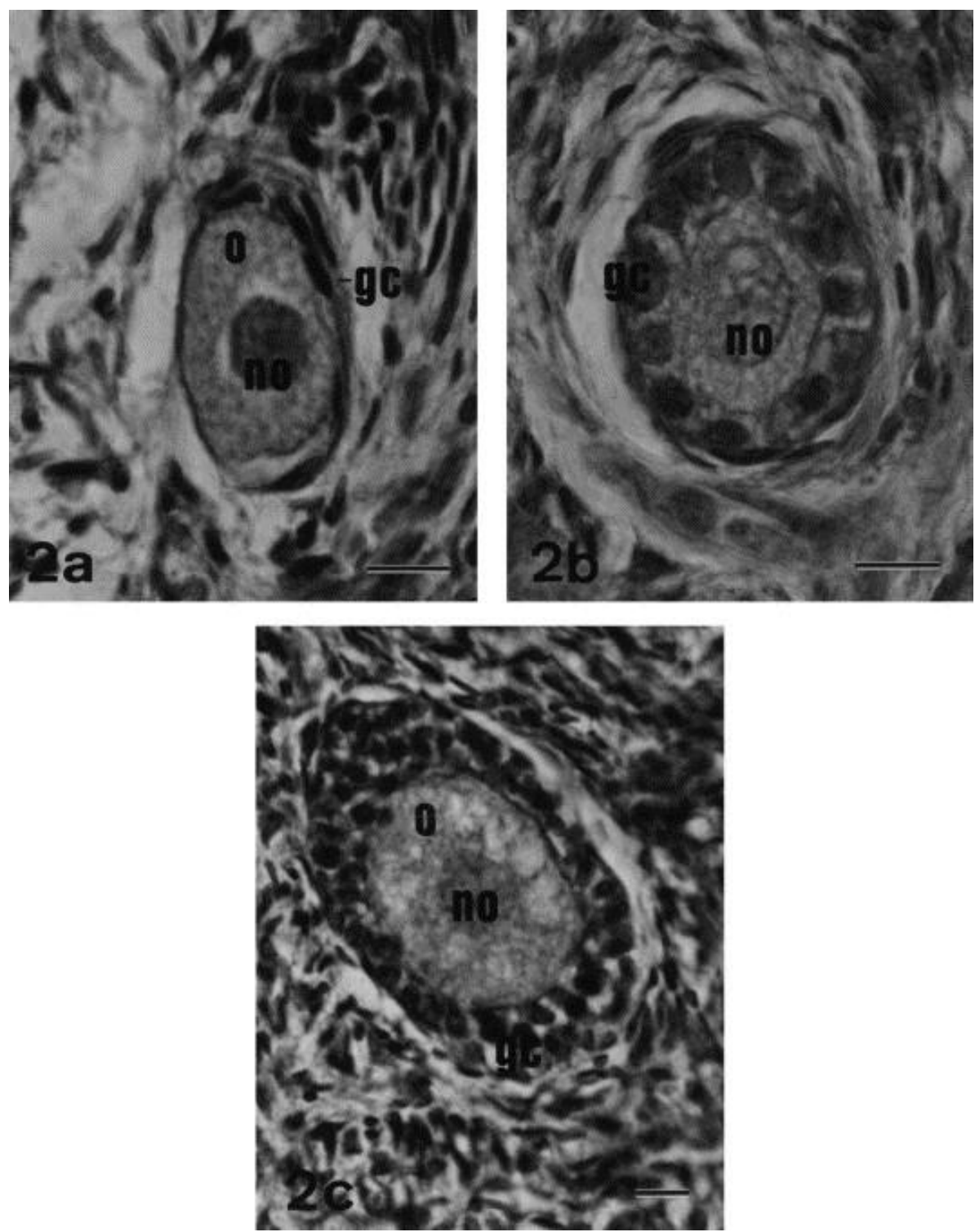

Fig. 2. Histological sections of the ovary, showing (a) primordial, (b) primary and (c) secondary follicles. O: Oocyte; NO: Nucleus of oocyte; GC: Granulosa cells. Bars $=10 \mu \mathrm{m}$.

Table 3 shows the diameter of primordial, primary and secondary follicles in situ and after isolation. The diameters of isolated primary and secondary follicles were significantly greater than those observed in situ. A significant difference among the diameters of the three follicular classes was also observed, both in situ and after isolation. 
Table 3.

Diameter in $\mu \mathrm{m}$ (mean \pm s.e.m.) of primordial, primary and secondary follicles in situ and after isolation

\begin{tabular}{|c|c|c|c|c|}
\hline \multirow[t]{2}{*}{ Follicular class } & \multicolumn{4}{|c|}{ Mean diameter $(\mu \mathrm{m})$ (ranger) } \\
\hline & $N$ & & $N$ & Isolated \\
\hline Primordial & 162 & $20.05 \pm 0.31^{\mathrm{aA}}$ & 322 & $21.51 \pm 0.21^{\mathrm{aA}}(12.90-32.25)$ \\
\hline Primary & 162 & $24.42 \pm 0.32^{\mathrm{aB}}$ & 81 & $32.40 \pm 0.57^{\mathrm{bB}}(25.80-51.60)$ \\
\hline Secondary & 48 & $44.24 \pm 3.61^{\mathrm{aC}}$ & 29 & $58.94 \pm 3.55^{\mathrm{bc}}(32.25-122.55)$ \\
\hline
\end{tabular}

Secondary $\quad 48 \quad 44.24 \pm 3.61$

$A, B, C$ Values with different superscripts in the same column are significantly different $(p<0.0003)$ 
In regard to histological evaluation of the goat ovaries, the analyzed sections showed that primordial follicles were always located in the outer part of the cortex. Primary follicles were found in the outer and inner parts of the cortex, while secondary follicles were distributed only within the inner part of the cortex.

Polyovular preantral follicles were commonly observed (Fig. 3), more frequently in primordial, but also in primary and secondary follicles, and mainly in ovaries of prepubertal animals. In prepubertal, non-pregnant and pregnant goats, polyovular follicles were observed, respectively, in $100 \%(6 / 6), 50 \%(3 / 6)$ and $17 \%(1 / 6)$ of the ovaries studied. The number of oocytes within the same follicle varied from 2 to 9 for primordial follicles, and from 2 to 3 for primary follicles. Polyovular secondary follicles had no more than two oocytes. The total number of polyovular preantral follicles was not evaluated for lack of parameters of calculation. In isolated follicles, only one case of a polyovular follicle was observed.

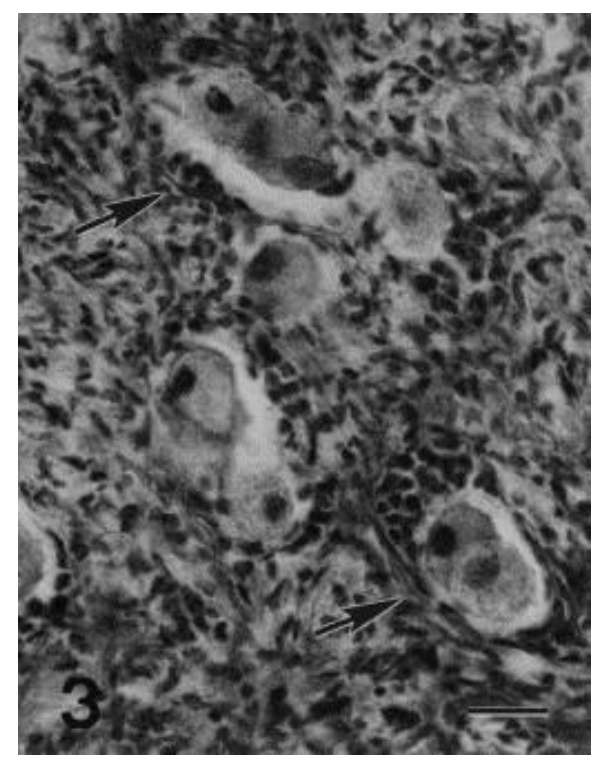

Fig. 3. Histological section of the ovary of prepubertal goat, showing polyovular follicles (arrows). Bar=20 $\mu \mathrm{m}$.

\subsection{Quality of preantral follicles in situ and after mechanical isolation}

Histological analysis showed that the vast majority of preantral follicles were morphologically normal (Fig. 4a) and only a few preantral follicles were atretic in situ and after the isolation procedure in the three reproductive stages. Taking the data together, the percentage of atretic follicles was $4.7 \% \pm 0.7$ for isolated follicles and $4.8 \% \pm 0.4$ for follicles in situ. No differences among reproductive stages were observed. Retraction of the oocyte and/or condensation of its nucleus (Fig. 4b) characterized the follicular degeneration more frequently observed. Pycnotic bodies were not observed in granulosa cells in the degenerated follicles, in situ or after isolation. Irregular spaces between the layers of granulosa cells were 
found in secondary follicles in situ. The significance of these spaces is unclear, and due to the absence of pycnotic granulosa cells or degenerating oocytes, these follicles were classified as healthy.
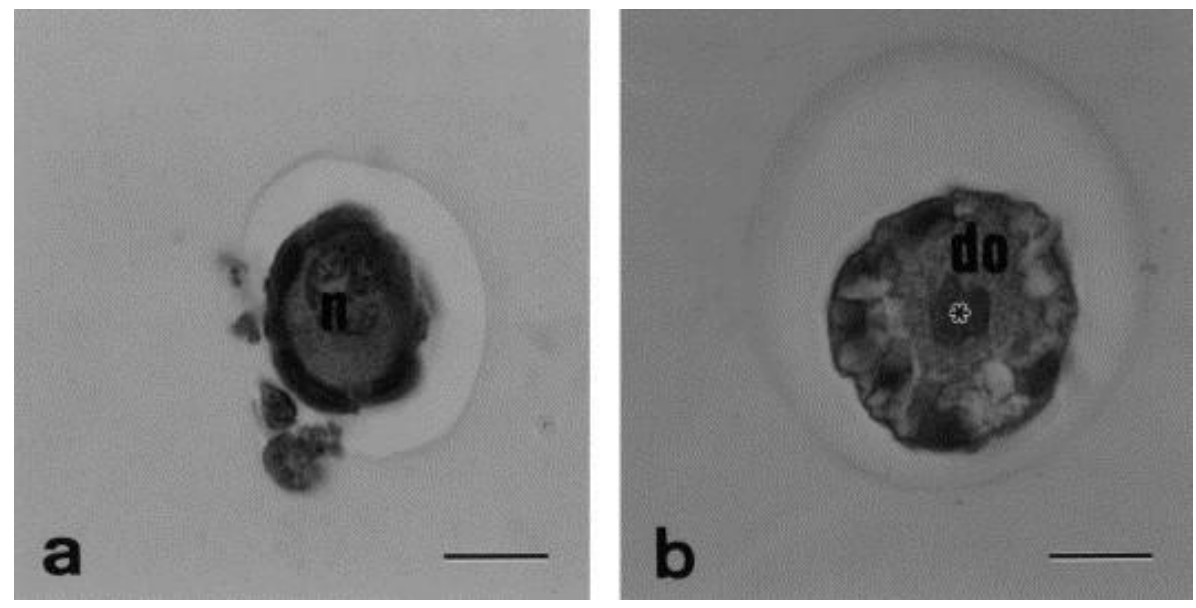

Fig. 4. Histological sections of (a) a morphologically normal follicle and (b) a degenerated follicle, after isolation. N: Nucleus of a normal oocyte, DO: Degenerating oocyte (* marks condensed nucleus). Bars $=10 \mu \mathrm{m}$.

\section{Discussion}

This study shows for the first time an estimation of preantral follicular population in caprine ovaries. The results of this study showed that the ovaries of prepubertal and adult goats contain large numbers of preantral follicles (on average $37,646 \pm 4277$ ). A similar number of in situ preantral follicles was reported for sheep by Driancourt et al. (1985). Other authors reported greater numbers of preantral follicles in ovaries from ewes (Land, 1970) and cows (Erickson, 1966b). Besides the species differences, preantral follicle population may be affected by many factors including breed (Cahill et al., 1979). It is important to note that all the animals used in the present study were mixed breed goats. Although the age (Erickson, 1966a and Erickson, 1966b) and reproductive stage (Erickson et al., 1976) may also affect the preantral follicular population, in the present study no differences were observed in the number of preantral follicles in situ among prepubertal, non-pregnant and pregnant adult goats. According to Erickson (1966b), in cattle the number of preantral follicles remains stable until the fourth year of life. An influence of puberty on the total number of preantral follicles in cattle was not observed, consistent with the results for goats presented here.

The results showed that the specific mechanical method developed for the isolation of preantral follicles from caprine ovaries can be successfully used to isolate a large number of well preserved preantral follicles from prepubertal, non-pregnant and pregnant goats. Although many papers have shown that mechanical and/or enzymatic methods allow the 
isolation of a large number of preantral follicles per ovary, no information is available concerning the efficiency of such methods based on the population of preantral follicles present in the ovary. Taking into consideration that the population of preantral follicle may be affected by many factors, for the best evaluation of the isolation methods, it is important to use the same ovary or at least the contralateral ovary as a control. Using the same experimental design described in the present paper, recent work with ovine ovaries shows that the specific mechanical isolation procedure can recover about $27 \%$ of the entire population of preantral follicles from adult ewes, and about $5 \%$ from fetal lambs (Amorim et al., 1998a). In our study, the specific mechanical method for the isolation of preantral follicles from caprine ovaries recovered about $36 \%$ of the entire population of preantral follicles from goats, irrespective of the reproductive stage (prepubertal, non-pregnant and pregnant adult animals).

In this study, the proportions of primordial, primary and secondary follicles were different in situ than after isolation. The procedure used to isolate preantral follicles in the present study was shown to be more efficient to isolate primordial than primary and secondary follicles. Primordial follicles formed $93.8 \%$ of the isolated preantral follicles, whereas primary and secondary follicles formed 5.2\% and 1.0\%, respectively. Previous studies provided similar results in the isolation of preantral follicles using a tissue chopper (Rodrigues et al., 1998; Lucci et al., 1999; Amorim et al., unpublished results). In contrast, Hulshof et al. (1994), using watchmakers forceps to isolate preantral follicles, observed a low percentage of isolated primordial follicles (12.5\%) when compared to primary $(57.2 \%)$ and secondary $(20.7 \%)$ follicles. These authors suggested that results be due to primordial follicles being tightly embedded in the tunica albuginea (Greenwald and Moor, 1989), and a mild mechanical treatment is not sufficient to isolate primordial follicles. Large numbers of primordial follicles were easily isolated from pig ovaries using a combined mechanical and enzymatic method (Greenwald and Moor, 1989), suggesting that an enzymatic treatment of the ovaries may be necessary to isolate this class of preantral follicles. We suggest that the use of the tissue chopper is a more powerful method to isolate a great numbers of primordial follicles without additional enzymatic treatment. In general, this mechanical method isolated about $50.2 \%$, $5.9 \%$ and $5.5 \%$, respectively, of the total primordial, primary and secondary follicles present in the goat ovaries.

In the present study, the diameters of the freshly isolated preantral follicles were greater than those measured in ovarian tissue sections. This may be due to shrinkage of the tissue after histological procedures. The diameters of isolated primordial, primary and secondary follicles from caprine ovaries were similar to those observed for sheep (Amorim et 
al., unpublished results) and goats (Rodrigues et al., 1998), but were smaller than those reported for bovine fetuses (Hulshof et al., 1994). In situ, the diameters of caprine preantral follicles were also smaller than those in ovaries from bovine fetuses (Hulshof et al., 1994). These differences may be species-specific or due to differences in histological techniques. The location of primordial, primary and secondary follicles in the cortex of caprine ovaries was similar to that described to sheep (Hadek, 1958) and monkeys (Koering et al., 1991).

In this study, many polyovular follicles were observed, mainly in ovaries of prepubertal animals and more frequently in primordial follicles. Hadek (1958) reported that polyovular follicles are commonly found in ovine ovaries. Polyovular follicles were also found in bitches (McDougall et al., 1997) and pigs (Greenwald and Moor, 1989). Nuttinck et al. (1993) observed one case of a biovular follicle in a population of isolated bovine preantral follicles. According to Rüsse (1983), in fetal life, the oogonia are found side by side, forming clusters in the gonads of cattle and sheep. The accompanying somatic cells, which are probably the precursors of the follicular cells, are also included in the clusters. Starting from the second third of gestation, the isolation of the oocytes starts with an increase in the number of accompanying somatic cells. We suggest the possibility that the isolation of the oocytes, is sometimes not complete in goats, giving rise to polyovular follicles that persist in postnatal life. McDougall et al. (1997) suggested that a population of oocytes from one germ cell may remain held together in a polyovular follicle. However, the precise role of polyovular follicles in mammalian ovary remains unknown. It would be interesting in the future to investigate the possible development of these follicles in vitro.

The small number of degenerated follicles observed in this study is confirmed by other authors (Cahill et al., 1979; Jorio et al., 1991). The histological analysis of preantral follicles, in situ and of isolated follicles, showed that the degeneration is characterized by oocyte alterations and pycnotic bodies were not observed in granulosa cells. Jorio et al. (1991) described that degeneration of the oocyte is the mode of atresia more frequently observed in preantral follicles. Although pycnosis of granulosa cells occurs in follicles with an antrum, it is almost absent in preantral follicles. Hirshfield (1983) also reported that in secondary follicles, between $75 \mu \mathrm{m}$ and $150 \mu \mathrm{m}$ of diameter, the oocyte degeneration was usually the only sign of atresia. In bovine preantral follicles, Figueiredo et al. (1994) found that the follicular degeneration is characterized by a rapid and early disappearance of the oocyte which often occurs before structural follicular changes become visible under the inverted microscope. In a study in vitro, Braw-Tal and Yossefi (1997) related that in some preantral follicles the oocyte degenerated or completely disappeared while granulosa cells looked healthy and continued to proliferate, showing that the oocyte is much more sensitive degeneration events than the 
granulosa cells. The secondary follicles with irregular spaces between the layers of granulosa cells were classified as healthy, since they did not have pycnotic granulosa cells or degenerated oocyte. Such classification was supported by the findings of Hirshfield (1983). This author also suggests that these irregular spaces are a sign of premature antrum formation.

In conclusion, this work shows for the first time an estimation of the population of preantral follicles in caprine ovaries. Moreover, a large number of preantral follicles was successfully isolated, with a high recovery rate and a low rate of follicular degeneration, from ovaries of prepubertal, non-pregnant and pregnant goats using a specific mechanical method.

\section{Acknowledgements}

This study was supported by the Laboratório de Morfologia e Morfogênese and the Laboratório de Microscopia Eletrônica of University of Brasília, Brazil, Laboratório de Ciências do Mar of Federal University of Ceará, Brazil and University of Liège, Belgium. The authors thank Antônio Djalma Santos for technical assistance and Zélia Ramos Madeira for the English correction of the manuscript.

\section{References}

Amorim, C.A., Lucci, C.M., Rodrigues, A.P.R., Carvalho, F.C.A., Figueiredo, J.R., Gonc, alves, P.B.D., 1998a. Efficiency of the specific mechanical method for the isolation of preantral follicles from ovine ovaries. Arq. Fac. Vet. UFRGS, Porto Alegre 261,211 , Suppl.

Amorim, C.A., Rodrigues, A.P.R., Lucci, C.M., Figueiredo, J.R., Gonc, alves, P.B.D., 1998b. Mechanical method for the isolation of preantral follicles from adult ovine ovaries. Arq. Fac. Vet. UFRGS, Porto Alegre 261,215 , Suppl.

Betteridge, K.J., Smith, C., Stubbings, R.B., Xu, K.P., King, W.A., 1989. Potential genetic improvement of cattle by fertilization of fetal oocytes in vitro. J. Reprod. Fertil. 38, 87-98.

Braw-Tal, R., Yossefi, S., 1997. Studies in vivo and in vitro on the initiation of follicle growth in the bovine ovary. J. Reprod. Fertil. 109, 165-171.

Cahill, L.P., Mauleon, P., 1981. A study of the populations of primordial and small follicles in the sheep. J. Reprod. Fertil. 61, 201-206.

Cahill, L.P., Mariana, J.C., Mauleon, P., 1979. Total follicular populations in ewes of high and low ovulation rates. J. Reprod. Fertil. 55, 27-36.

Driancourt, M.A., Cahill, L.P., Bindon, B.M., 1985. Ovarian follicular populations and preovulatory enlargement in Booroola and control merino ewes. J. Reprod. Fertil. 73, 93-107.

Erickson, B.H., 1966a. Development and radio-response of the prenatal bovine ovary. J. Reprod. Fertil. 10, 97-105. 
Erickson, B.H., 1966b. Development and senescence of the postnatal bovine ovary. J. Anim. Sci. $25,800-805$.

Erickson, B.H., Reynolds, R.A., Murphree, R.L., 1976. Ovarian characteristics and reproductive performance of the aged cow. Biol. Reprod. 15, 555-560.

Figueiredo, J.R., Hulshof, S.C.J., Van Den Hurk, R., Ectors, F.J., Fontes, R.S., Nusgens, B., Bevers, M.M., Beckers, J.F., 1993. Development of a combined new mechanical and enzymatic method for the isolation of intact preantral follicles from fetal, calf and adult bovine ovaries.

Theriogenology 40, 789-799.

Figueiredo, J.R., Hulshof, S.C.J., Van Den Hurk, R., Nusgens, B., Bevers, M.M., Ectors, F.J., Beckers, J.F., 1994. Preservation of oocyte and granulosa cell morphology in bovine preantral follicles cultured in vitro. Theriogenology 41, 1333-1346.

Gougeon, A., Chainy, G.B.N., 1987. Morphometric studies of small follicles in ovaries of women at different ages. J. Reprod. Fertil. 81, 433-442.

Greenwald, G.S., Moor, R.M., 1989. Isolation and preliminary characterization of pig primordial follicles. J. Reprod. Fertil. 87, 561-571.

Hadek, R., 1958. Morphological and histochemical study in the ovary of the sheep. Am. J. Vet. Res. 19 (73) , 873-881.

Hirshfield, A., 1983. Compensatory ovarian hypertrophy in the long-term hemicastrate rat: size distribution of growing and atretic follicles. Biol. Reprod. 28, 271-278.

Hulshof, S.C.J., Figueiredo, J.R., Beckers, J.F., Bevers, M.M., Van Den Hurk, R., 1994. Isolation and characterization of preantral follicles from foetal bovine ovaries. Vet. Q. $162,78-80$.

Jewgenow, K., Pitra, C., 1993. Hormone-controlled culture of secondary follicles of domestic cats. Theriogenology 39, 527-535.

Jewgenow, K., Goritz, F., 1995. The recovery of preantral follicles from ovaries of domestic cats and their characterization before and after culture. Anim. Reprod. Sci. 39, 285-297.

Jorio, A., Mariana, J.C., Lahlou-Kassi, A., 1991. Development of the population of ovarian follicles during the prepubertal period in D'man and Timahdite sheep. Anim. Reprod. Sci. 26, 239-250.

Koering, M.J., Danforth, D.R., Hodgen, G.D., 1991. Early folliculogenesis in primate ovaries: testing the role of estrogen. Biol. Reprod. 45, 890-897.

Land, R.B., 1970. Number of oocytes present at birth in the ovaries of pure and Finnish Landrace cross Blackface and Welsh sheep. J. Reprod. Fertil. 21, 517-521.

Lazzari, G., Galli, C., Moor, R.M., 1992. Centrifugal elutriation of porcine oocytes isolated from the ovaries of newborn piglets. Anal. Biochem. 200, 31-35. 
Lucci, C.M., Amorim, C.A., Báo, S.N., Figueiredo, J.R., Rodrigues, A.P.R., Silva, J.R.V., Gonc' alves, P.B.D., 1999. Effect of the interval of serial sections of ovarian tissue in the tissue chopper on the number of isolated caprine preantral follicles. Anim. Reprod. Sci. 56, 39-49.

McDougall, K., Hay, M.A., Goodrowe, K.L., Gartley, C.J., King, W.A., 1997. Changes in the number of follicles and of oocytes in ovaries of prepubertal, peripubertal and mature bitches. J. Reprod. Fertil. 51, 25-31, Suppl.

Nuttinck, F., Mermillod, P., Massip, A., Dessy, F., 1993. Characterization of in vitro growth of bovine preantral ovarian follicles: a preliminary study. Theriogenology $394,811-821$.

Rodrigues, A.P.R., Amorim, C.A., Lucci, C.M., Figueiredo, J.R., Gonc, alves, P.B.D., Bem, A.R., 1998. Isolamento mecanico de folıculos ovarianos pre-antrais em cabras. Ciencia Rural 283 , 477-482.

Rüsse, I., 1983. Oogenesis in cattle and sheep. Bibl. Anat. 24, 77-79. 